\title{
Kronik boyun ağrılarında girişimsel yöntemler
}

\section{Interventional methods in chronic neck pain}

\author{
Süleyman Özyalçın ${ }^{1}$, Halil Çetingök ${ }^{2}$ \\ ${ }^{1}$ Algo Ağrı Tanı ve Tedavi Merkezi, İstanbul \\ ${ }^{2}$ İstanbul Üniversitesi, İstanbul Tıp Fakültesi, İstanbul
}

\begin{abstract}
Kronik boyun ağrıları, hastaların en sık hekime başvuru nedenlerinden biridir. Günümüzde sedanter hayat ve genel olarak obezitenin artmış olması, kronik bel ve boyun ağrılarının sıklığında artmaya neden olmaktadır. Pek çok farklı yapıdan kaynaklanabilen kronik boyun ağrılarının başarılı tedavisi, öncelikle hastadan alınacak iyi bir anamnez ve fizik tedavinin yanında, görüntüleme yöntemlerinin kullanılmasını gerektirir. Ağrı nedeninin doğru saptanması, hedefe yönelik tedavilerin başarısını arttıran en önemli parametredir. Boyun ağrılarının konservatif tedavilere yanıt vermemesi ve kronikleşmesi halinde, girişimsel yöntemlere başvurulur. Çok ciddi komplikasyonları olabilecek bu yöntemlerin, gelişmiş merkezlerde ve deneyimli ekipler tarafindan, multidisipliner bir incelemenin sonucunda uygulanması gerekir.
\end{abstract}

Anahtar sözcükler: kronik boyun ağrısı; girişimsel tedavi; algoloji
Chronic neck pain is one of the most common causes of treatment for patients. Today, sedentary life and increased obesity in general, cause an increase in the frequency of chronic back and neck pain. Successful treatment of chronic neck pain, which may arise from many different structures, requires the use of imaging methods as well as good anamnesis and physical therapy of the patient. Correct detection of the cause of pain is the most important parameter that increases the success of targeted treatments. If neck pain does not respond to conservative treatments and becomes chronic, interventional methods are used. These methods which may have serious complications, should be performed in developed centers and by experienced teams, following a multidisciplinary study.

Key words: chronic neck pain; interventional therapy; pain medicine ünümüzde, özellikle kol kullanımının artması ve iş yerlerinde kullanılan bazı araçların (daktilo, bilgisayar, dokuma tezgahları, vb.) yaygınlaşması, boyun ağrılarının artmasına, boyun ve kol ağrılarının toplumların en yaygın sorunlarından biri halini almasına yol açmıştır. ${ }^{[1,2]}$

Servikal omurga, kafa tabanından başlayan ve torakal (gögü̈s, sırt) omurgalarda (T1) sonlanan yedi omurgadan oluşmaktadır. Bu kemik yapılar, rahat hareketi sağlamak amacı ile bağlar (ligaman) ile birbirlerine bağlanmıştır. Bağların çevresindeki kaslar, destek sağlar ve harekete yardımcı olur. Boyun omurgaları, kendilerinden beklenmeyecek kadar yük kaldırmakla birlikte, tüm omurganın en korunmasız bölümüdür. Bu nedenle, herkes belli dönemlerde boyun ağrısı çekmiştir. Birçok kişi için boyun ağrısı, zamanla kendiliğinden geçen bir rahatsızlık iken, bunlardan bir kısmı için tıbbi tanı ve tedavi gerektiren bir sürece dönüşür. ${ }^{[2]}$
Boyun ağrısı; bağlar, kaslar, bağ dokusu gibi yumuşak dokulardan kaynaklanacağı gibi, sinirlerden ve/ veya eklemlerden de kaynaklanabilir. En sık görülen boyun ağrısı nedeni, çeşitli etiyolojik faktörlere bağlı olarak ortaya çıkan yumuşak doku hasarıdır. Daha seyrek olarak, enfeksiyon ya da tümörler boyun ağrısına yol açabilir. Ayrıca boyun ağrısı, yansıyan ağrı şeklinde, yani sırtın üst bölümünün, omuzların, kolların problemlerinin yansıması olarak da gözlenebilir. ${ }^{[2]}$ Dejeneratif ve inflamatuvar hastalıklar (kemik ve eklemlerdeki doğal yapının bozulması), özellikle 40 yaşından sonra boyun ağrılarının ortaya çıkmasında önemli rol oynar. Romatoid artrit, osteoartrit, disk dejenerasyonu ve dar kanal bu bozukluklar arasındadır. ${ }^{[2]}$

Servikal bölge, oldukça hareketlidir ve her yöne eğilebilir bir konumdadır. Birinci omurga olan atlas, mitolojide dünyayı havada tutan "Atlas" gibi başı

- Illetişim adresi: Prof. Dr. Süleyman Özyalçın, Algo Ağrı Tanı ve Tedavi Merkezi, İstanbul

Tel: 0533 - 2960949 e-posta: ozyalcins@gmail.com

- Geliș tarihi: 20 Șubat 2017 Kabul tarihi: 20 Șubat 2017 
ayakta tutar. Başın dik tutulması, boyunun da dik tutulmasını sağlar. Boyun bölgesinden (boyunun ön tarafından), trakea, özofagus, önemli damarlar ve sinirler geçer. Boyun ağrısı ya da boyunun herhangi bir bölgesinde ortaya çıkan ağrı, erişkin popülasyonda oldukça sık gözlenir. Bu durum, yaşın artması ile doğru orantılı olarak da artmaktadır. Yapılan değerlendirmelerde, her 10 kişiden birinin boyun ağrısı problemi olduğu ortaya çıkmıştır. Bu rakam toplumun \%10'u demektir ki, oldukça yüksek bir orandır. Boyun ağrısı, boynu oluşturan farklı dokulardan ve bu farklı dokuların farklı problemlerinden kaynaklanabilir; basit bir kas kasılmasından merkezi sinir sistemi hastalıklarına kadar, geniş bir yelpazenin habercisi olabilir. Bazı durumlarda, seyrek de olsa kalp hastalığına bağlı göğüs ağrısı ya da yüksek tansiyona bağlı baş ağrısı boyunda duyulabilir. Çocuklarda, özellikle servikal bölgenin anatomik anomalileri ve yapı bozuklukları boyun bölgesinde ağrı nedeni olabilir. Baş ağrısının dışında, boyun ağrısına omuz-kol ağrısı, sersemlik, baş dönmesi, ataksi, kulak çınlaması, görme bozuklukları, bazen bilinç kaybı eşlik eder. Bu bulgular, boyun omurgalarının dışında, beyni besleyen damarların problemlerinden de kaynaklanabilir. ${ }^{[1,2]}$

\section{ANATOMIK ÖZELLIKLER}

Sevikal omurlar, tüm vertebral kolonun en geniş çapta hareket yeteneğine sahip bölgesini meydana getirir. $\mathrm{Bu}$ geniş hareket olanağı, servikal bölgede bulunan yedi servikal omur, beş intervertebral disk, 12 Luschka eklemi, 14 faset eklem ve çeşitli bağ ve adaleler ile sağlanmaktadır.

Servikal bölge, anterior ve posterior olmak üzere iki bölüme ayrılmıştır. Anterior bölümü diskler, omurgalar ve bunlara ait longitudinal bağlar; posterior bölümü ise nöroforaminal kanallar posterior bağlar, faset eklemler ve omurlara ait erektör adaleler oluşturur.

En yaygın tanımlamaya göre, servikal omurlar üst segment (C1-C2) ve alt segment (C3-C7) olarak iki hareket ünitesine ayrılmıştır. Bu iki bölgede, hem omurların anatomik yapıları hem de fonksiyonel özellikleri farklıdır. Kısaca, fleksiyon, ekstansiyon, rotasyon ve yanlara fleksiyon olarak sıralanabilen servikal omur hareketleri, bu farklı özelliklere sahip üst ve alt segment omurları ile sağlanır. ${ }^{[2]}$

\section{Üst Servikal Segment (Üst Fonksiyonel Ünite)}

Bu bölge, oksipito-atlantal (kafa tabanına ait oksipital bölge ve ilk omur olan atlas) ile atlanto-aksiyel (atlas ve ikinci omur olan aksis) bölümlerden oluşur.
Oksipito-atlantal eklemin elemanlarından biri olan atlas (C1), solid bir çember özelliğinde ve gövdesi olmayan bir omurdur. Oksipital kemik ile birleşen atlasın yanlarında bulunan iki adet konkav yapılı superior faset eklem, sagittal planda başın fleksiyon ve ekstansiyon hareketini sağlar. Fleksiyon $10^{\circ}$, ekstansiyon $25^{\circ}$ olmak üzere, bu hareketin genişliği toplam $35^{\circ}$ olmalıdır. Atlasın oldukça uzun olan transvers çıkıntılarına ait foraminalarda, vertebral arter, ven ve sempatik pleksuslar bulunur. Transvers çıkıntı civarındaki adaleler, başın rotasyon hareketine yardımcı olur. ${ }^{[2]}$

Atlantoaksiyel eklem elemanlarından aksis (C2), çiviye benzeyen bir çıkıntı yapan (odontoid oluşum = dens) küçük bir gövdeye sahiptir. Odontoid oluşum, atlasın rotasyonunu sağlayarak dönme hareketini oluşturur. Sağa ve sola $45^{\circ}$ olmak üzere $90^{\circ}$ 'lik bu geniş rotasyon hareketi, $\mathrm{C} 1$ 'in C2 üzerinde odontoid oluşum sayesinde dönmesi ile gerçekleşir. Atlasın alt yüzeyi aksisin superior faset eklemleri ile birleşir. Bu eklemler, başın yanlara ve ileri doğru hareketini sağlar. Ayrıca, superior faset eklemler sagittal planda fleksiyon ve ekstansiyon hareketine yardımcı olur; yanlara ve rotasyona yönelik hareketleri kısıtlar. Böylece, aşırı lateral fleksiyon ve rotasyon önlenmiş olur. Atlantoaksiyel ve oksipito-atlantal eklem ünitelerinde, omurlar arasında disk oluşumu yoktur. Aksis ile üçüncü servikal omur arasında disk oluşumu vardır. Üçüncü servikal omurun superior fasetleri ile aksis arasındaki eklem yapısı ve bu omurlar arasındaki disk oluşumu, bu bölgedeki hareketlerin aşırı yapılmasını önleyici bir özellik taşır. ${ }^{[2]}$

Atlantoaksiyel eklem bağları, spinal kanalı (spinal kord ve sinir köklerini) travmaya karşı koruyucu rol oynar. Oksipitalatlas-aksis bağları; apikal bağ, alar bağ ve transvers bağ olarak üçe ayrılır. Bu bağlar, rotasyon hareketini sınırlandırdığı gibi, aksis üzerinden oksipito-atlas bileşiminin yana subluksasyonunu önler. Omurgaların posterior yüzeyinde bulunan ve diske destek bir yapı özelliğinde olan posterior longitudinal bağ, boynun aşırı fleksiyon ve ekstansiyon hareketini önler. Ligamentum flavum, atlasın posterior kenarından aksis laminasına doğru uzanır; oksipito-atlantal bileşiminin aksis üzerinden ileri doğru subluksasyonunu önler. Kafa tabanından, foramen magnum çevresinden başlayarak vertebraların spinöz çıkıntılarını birleştiren ligamentum nuchae, boynun arkaya doğru hareketlerine yardımcı olur ve $C 7$ altında supraspinöz bağ olarak devam eder. ${ }^{[2]}$

\section{Alt Servikal Segment (Alt Fonksiyonel Ünite)}

C1 ve $C 2$ dışındaki diğer beş servikal omurgada (C3-C7); bir omur gövdesi, iki pedikül, iki lamina ve bir spinöz çıkıntı bulunur. C3 ve $\mathrm{C} 6$ arasındaki tüm 
tranvers çıkıntılarda; vertebral arter, ven ve sempatik sinir veya pleksusu kapsayan bir oluk (transvers foramen) bulunur. C3-C7 arası servikal omurların anterior kısmı posteriordan daha uzundur. Aynı zamanda, intervertebral disklerin de anterior bölgede posteriordan daha geniş olması, servikal lordotik yapının oluşumunu sağlar. Alt segmentte; intervertebral diskler, anterior ve posterior bağlar, faset eklemler, ligamentum flavum, ligamentum nuchae, intertransvers bağ ve interspinöz bağ bulunur. Bu bölgedeki fonksiyonel hareketler, lumbar bölgedeki omurların özelliği ile benzerlik gösterir ve ön yüzde ağırlık taşımaya karşı direnci, arka yüzde ise omurların kayma hareketinin sağlanmasını içerir. ${ }^{[2]}$

\section{Boyun Bölgesi Adaleleri}

Boyun adaleleri, fleksör ve ekstansör hareketi sağlayan iki büyük gruba ayrılır. Boynun fleksör hareketini yapan ana adaleler; longus kapitis, rektus kapitis anterior ve lateral ile hiyoid ve suprahiyoid adalelerdir. Boynun ekstansör hareketini sağlayan kısa adaleler, kafa tabanı ile atlas arasında uzanır. Ana ekstansörler olan bu adaleler; rektus kapitis minör ve majör ile oblikus kapitus superior ve inferior adaleleridir. Ayrıca, semispinalis kapitis, longissimus kapitis ve splenius kapitis adaleleri de, ekstansör hareketini sağlar. Uzun adaleler olan splenius kapitis ve splenius servisis, rotasyon hareketini gerçekleştirir. Aynı zamanda, bilateral kontraksiyonla, ekstansör hareket üzerinde de etkilidir. Üst torasik omur ve skapula arasında uzanan levator skapula ve trapez adaleleri, bu alandaki diğer adaleler ile birlikte, servikal omurların rotasyon ve yanlara fleksiyon hareketine yardımcı olur. Üst servikal segmentin ekstansör hareketi, atlanto-aksiyel eklem bölgesinden kaynaklanır. Fleksör adaleler ise daha çok orta servikal bölgede (C4-C5) bulunur. Boyun hareketlerinde oynadıkları rol nedeniyle travmaya uğrayan bu adaleler, aynı zamanda boyun bölgesinde ağrılı tetik noktaları da kapsar. ${ }^{[2]}$

\section{Servikal Sinirler ve Ağrı}

Servikal bölgede de diğer spinal sinirler gibi, spinal kord gri maddeden kaynaklanan, anterior (ventral) motor ve posterior (dorsal) sensoriyel sinir liflerinin vertebral alanı terk etmeden önce bilateral olarak birleşmesi ile oluşan, tek tek kökler vardır (Şekil 1). Fonksiyonel ünitede üst ve alt servikal segmentte farklılıklar olduğu gibi, servikal sinirlerde üst ve alt segmentler de farklılıklar taşımaktadır.

Üst servikal sinirler (C1-C2 ve C3'ün dalı); baş, yüz ve boyun bölgesini innerve eder. Servikojenik baş ağrılarının bu bölgeden kaynaklandığı savunulmuştur.

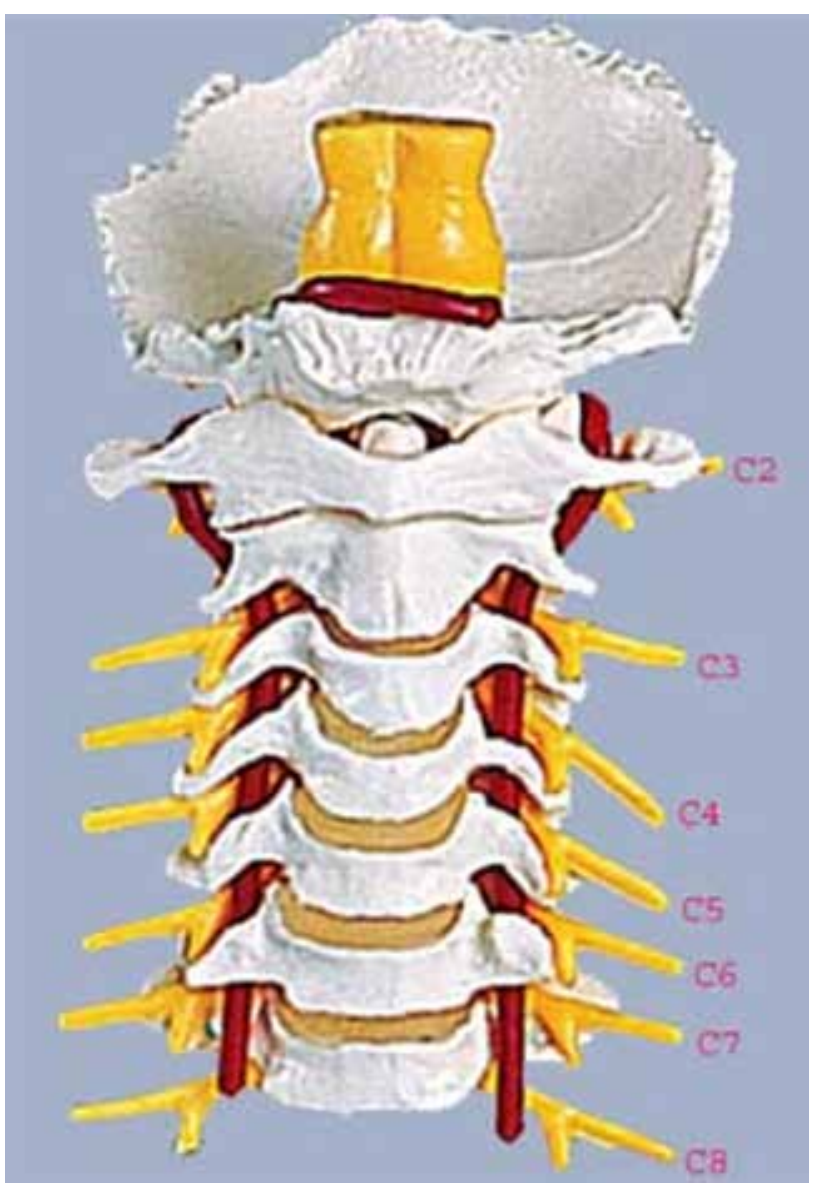

Şekil 1. Servikal spinal sinirler.

Üst üç servikal segmentten hangisinin ağrı iletimini sağladığı tam olarak aydınlanmamıştır. C1 kökü sensoriyel dağılımı bulunmamaktadır. Bu konudaki araştırmalarda, minör ve majör oksipital sinirin, servikal dorsal raminin mediyal dallarının, C2'nin ventral ramusunun ve üçüncü oksipital sinirin ağrı iletiminden sorumlu olduğu ileri sürülmüştür. Bu nedenle, servikojenik baş ağrıları, üst üç servikal kök ve periferik sinirlerin oluşturduğu üst servikal sendrom olarak da adlandırılır. Oksipital majör sinir (C2), baş ve yüz ağrılarının önemli bir nedenidir. Bu sinirin bası altında kalması, entrapmanı ve gerilmesi, boyundan alına ve yüze yayılan ağrılara neden olur. C3 ve $C 4$, boyun ve trapez adalesinin bir kısmını innerve eder. Ayrıca, oksiput atlas ve aksis arasında, diskler ve intervertebral foraminalar bulunmamaktadır. Bu bölgeden kaynaklanan şikayetler, disk seviyesi ve foramenler ile açıklanamaz. Oysa, alt servikal bölgeden kaynaklanan şikayetler, disklerde veya foraminalarla oluşan patolojilere bağlı olarak gelişir. Tanı 
Tablo 1. Alt servikal bölgede sinir basısı bulguları

\begin{tabular}{lllll}
\hline $\begin{array}{l}\text { Etkilenen } \\
\text { sinir kökü }\end{array}$ & Ağrılı bölge & Motor kayıp & Sensoriyel kayıp & Refleks değişiklikler \\
\hline C5 & Omuz ve üst kol & $\begin{array}{l}\text { Omuz adaleleri abduksiyon } \\
\text { ve eksternal rotatorlar }\end{array}$ & Omuzun yan ve üst kısımları & Biseps \\
C6 & Önkol radyal alanı & Biseps ve brakiyal adaleler & Önkol ve yumruğun radyal alanı & Yumruk ve brakiyoradyal refleksler \\
C7 & Önkol dorsal alanı & Triseps adalesi & İşaret parmağı ve orta parmak & Triseps refleksi \\
C8 & Önkol ulnar alanı & Elin intrensek adaleleri & Yüzük parmağı ve küçük parmak & Değişmez
\end{tabular}

konulması için, alt servikal bölgedeki çeşitli seviyelere ait köklerin nörolojik muayene ile ortaya konması gerekir (Tablo 1).

\section{Boyun Ağrısında Uygulanan İnvaziv Girişimler}

Son yıllarda, skopi tekniklerinin gelişmesi ve radyofrekans cihazlarının teknik donanımları ile geniş kullanım olanakları sunacak şekilde geliştirilmesi, bu alanda tedavi seçeneklerinin de artmasına yol açmıştır. Buna bağlı olarak, bu bölgede bulunan ve ağrı kaynağı oluşturan yapılara (sinir, adale, bağ, vb.) çeşitli diyagnostik ve terapötik girişim teknikleri geliştirilmiştir. Ancak, her girişimin bir takım olası komplikasyonları, uygulamada kısıtlamalara neden olur. Bu nedenle, bu yöntemlerin gelişmiş merkezlerde ve deneyimli ekipler tarafindan, multidisipliner bir incelemenin sonucunda uygulanması gerekir.

\section{Diyagnostik bloklar}

Faset eklemlere, sempatik gangliyonlara ve çeşitli somatik sinirlere, ağrı şikayetlerinin tanısına yönelik olarak geçici sinir blokları uygulanabilir. Lokal anestezik enjeksiyonu ile uygulanan bloklar, sadece diyagnostik amaçlı olmayıp, aynı zamanda yararlı etkiler doğuracak prognostik amaca da yönelik olabilir. Kalıcı blokların uygulanması, sadece diyagnostik blok sonrası pozitif yanıt alındığında endikedir. Uygulama, radyo-opak madde kullanılarak skopi altında yapılmalıdır. Böylece, iğnenin pozisyonu kontrol edilir. Blok sonrası yalancı pozitif yanıt (plasebo etkisi), tanıda yanılgılara yol açabilir. Bu nedenle, şüpheli bir yanıtın tanıyı etkilemesini önlemek için, bloğun tekrarlanarak yapılması önerilir. Düşük dozda lokal anestezikle, hatalı negatif yanıt ortaya çıkabilir. Blok sonrası hastanın, lokal anesteziğin farmakolojik etkisi süresince fizik muayenesi ve ağrı şikayetlerindeki değişiklikler ile eşlik eden semptomların takibi, oldukça önemlidir ve tanı koydurucudur.

Diskojenik ağrı veya spinal sinirlerin patolojisine bağlı oluşan segmental ağrının tedavisinde, servikal dorsal kök gangliyon lezyonları yararlı olabilir. Tedavilere dirençli C2-C3 faset ağrısının kontrolü için, C2 ve C3 gangliyon lezyonları oldukça etkilidir. Lezyon oluşturmadan önce, prognostik bloklar ile ağrılı segmentin doğru olarak saptanması çok önemlidir. Dorsal kök gangliyonu lezyonlarına bağlı olarak de-afferentasyon ağrısı ortaya çıkabileceği için, hastayı değerlendirmede prognostik bloklar veya diskografi mutlaka yapılmalıdır. Servikal diskojenik ağrıdan şüpheleniliyorsa, neden olan spesifik segmentin belirlenmesi için analjezik diskografi uygulanmalıdır. Selektif kök kılıfı enjeksiyonları da tanıda oldukça yararlıdır. C5-C6 diskinin ağrılı olduğundan kuşkulanılıyorsa, doğru tanının konulması için, hem aynı seviyeden diskografi hem de C6 düzeyinden selektif kök kılıfı enjeksiyonu yapılması önerilir.

Ağrılı segmentin kesin tanınabilmesi, sinir kök kılıfı içine lokal anestezik enjeksiyonu ile mümkündür. Diyagnostik ve prognostik sinir kök kılıfı bloğu için, omurgada bölgesel farklılıklar olsa da genellikle prensip aynıdır. Burada, enjeksiyon yapılacak bölgenin akciğerler ve vertebral arter gibi önemli yapılara yakınlığı önemlidir. Blok sırasında iğne yerleştirilirken, bu yapılara zarar vermemeye dikkat edilmelidir. Sinir kökleri de dikkat edilmesi gereken önemli yapılardır; dolayısıyla, iğneler sokulurken çok nazik davranmak gerekir. Lokal anestezik veya radyo-opak madde enjeksiyonunda da dikkatli olunmalı ve enjeksiyonlar çok yavaş olarak yapılmalıdır. Enjeksiyonlarda, sıvı volümleri de $0,5-1,5 \mathrm{ml}$ ile sınırlandırılmalıdır. Daha geniş volümler epidural aralıktan yakındaki sinir köklerine yayılacağı için, segmental kesinliğin kaybolmasına neden olur.

Tanı amacıyla ağrı yakınmalarına uygun dermatoma göre servikal epidural aralığa yerleştirilen kateterden, çeşitli konsantrasyonlarda hazırlanan lokal anestezik ilaç ve serum fizyolojik enjekte edilerek, diferansiyel blok uygulanabilir. Bu uygulama ile, ağrının somatik ya da sempatik kökenli olup olmadığı veya psikolojik nedenlerle ilişkisi hakkında fikir sahibi olunabilir. ${ }^{[3,4]}$ 

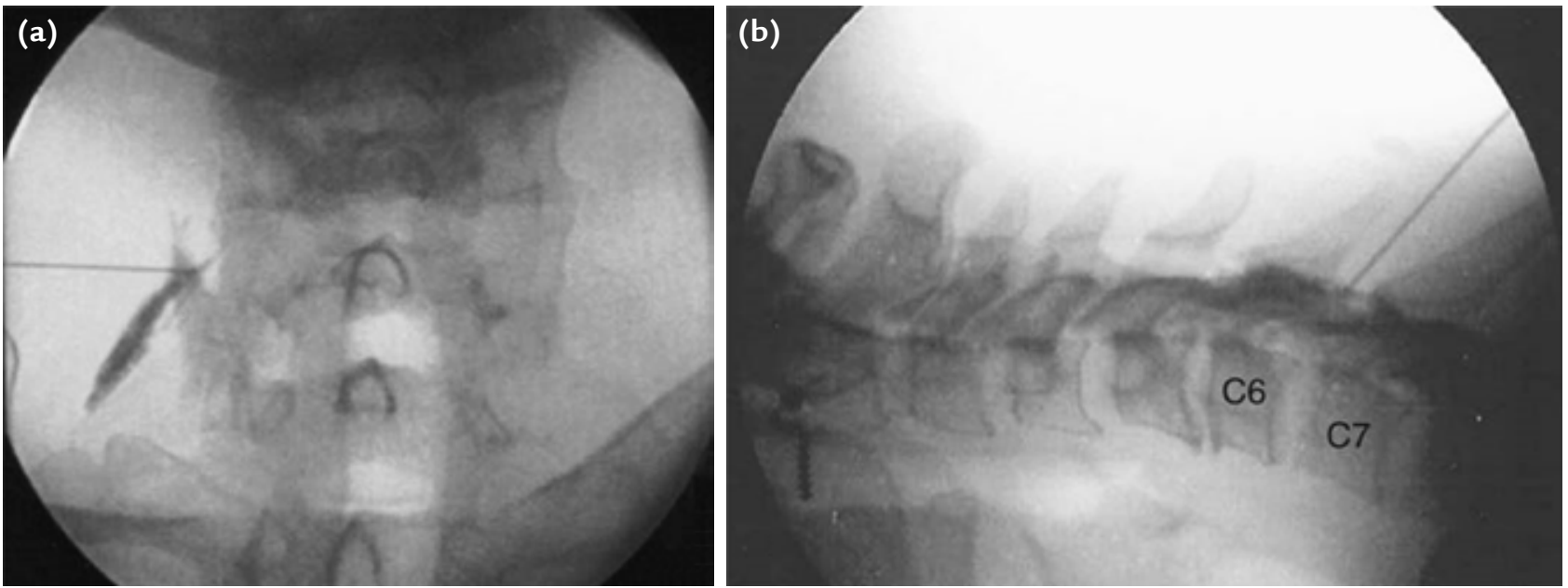

Şekil 2. a, b. Servikal transforaminal steroid enjeksiyonu (a). Servikal interlaminer steriod enjeksiyonu (b).

\section{Trigger nokta enjeksiyonu}

Baş-boyun ve omuz-kol ağrılarının en yaygın nedenlerinden biri, bu bölgelerde bulunan adale yapılarından kaynaklanan patolojilerdir. Boyun ve omuzda bulunan adalelerde oluşan miyofasyal ağrı sendromlarında, bu bölgeye yayılan ağrılı yakınmalar oluşur. Enjeksiyonlarda kuru iğnelemenin yeterli olduğunu savunan araştırmacılar olduğu gibi, serum fizyolojik, steroid, lokal anestezikler ya da bu ilaçların kombinasyonlarının kullanılmasını önerenler de vardır. Son yıllarda, bu amaçla botulismus toksini enjeksiyonunun da önerildiği yayınlar bulunmaktadır. Bu enjeksiyon uygulamaları, adale spazmını azaltarak, hem hareket kısıtlılığını hem de ağrı şikayetlerini tedavi edilebilir.

\section{Epidural enjeksiyonlar}

Disk hernisinde ya da bulging halinde, prostaglandin E, serotonin, histamin gibi nosiseptif ajanlar salınır. Bu ajanlar; ödem, inflamasyon ve sinir kökü irritasyonuna yol açar. Epidural steroid enjeksiyonu, prostaglandin E oluşumunu engelleyen fosfolipaz A2 inhibitörünün biyosentezini arttırarak, inflamasyonu azaltıp yapışıkIıkları çözer. Epidural alana steroid uygulanması, ilk kez 1953 yılında Lievre tarafindan, lumbar radikülopatiden yakınan 20 hastaya hidrokortizon enjekte edilmesi ile gerçekleştirilmiştir. Servikal epidural steroid enjeksiyonları ile ilgili ilk kez 1972'de anekdotal olarak bahsedilmesine karşın, 1980 öncesine ait araştırma yoktur. Servikal alanda epidural aralığın dar olması ve girişim sırasında medulla spinalis hasarı olasılığının bulunması gibi, servikal epidural steroid enjeksiyonu tekniğini zorlaştıran nedenlere bağlı olarak, bu uygulamaya ait sınırlı yayın bulunmaktadır. ${ }^{[5,6]}$

Epidural steroid enjeksiyonu, ağrılı dermatoma en yakın kökün bulunduğu seviyeden yapılmalıdır. Hasta, ağrılı tarafi alta gelecek şekilde lateral dekubitus pozisyonunda yatırılır. İşlem mutlaka ameliyathanede, steril koşullar altında skopi yardımı ile uygulanmalıdır. Direnç kaybı yöntemi ile, peridural aralığa girilir. Epidural alanda iğnenin yerleşimi, floroskopi ile kontrol edilmelidir (Şekil 2). Deneyimli kişilerde bile \%25 hatalı yerleşim olduğu göz önüne alınırsa, enjeksiyon öncesi radyo-opak madde ile Touhy iğnesinin yerleşimi, epidural alan olası intratekal kaçış ve yayılım dermatomu görüntülenmelidir. ${ }^{[5,6]}$

Epidural steroid enjeksiyonu, disk hernileri sonucu oluşan sinir kökü basısı ve irritasyonlarda çok etkilidir. Bu hastaların muayenesinde; radiküler ağrı, dermatomal hipoestezi, tutulu kas gruplarında güçsüzlük ve derin tendon reflekslerinde azalma saptanır.

Spinal stenoz, spondilolistezis veya spondilolizisli hastalarda epidural steroidlerin kullanımı tartışmalıdır. Bu hastalarda başlıca uygulama nedeni; geçici bir rahatlama sağlayıp, uygulanması gereken diğer tedavi yöntemlerine ve egzersiz uygulamalarına hastanın uyum sağlamasına yardımcı olmaktır. Bu hastalarda uygulama sonrası yetersiz yanıt, cerrahi endikasyon nedeni olabilir. Post-laminektomili hastalarda ise, genellikle eşlik eden araknoidit ve adhezyon gibi nedenler yüzünden, epidural steroid uygulamasına iyi yanıt alınamamaktadır. ${ }^{[5-7]}$ 
Epidural steroid uygulamasına ait mutlak kontrendikasyon, girişim bölgesinde enfeksiyon olmasıdır. Ayrıca, hemorojik diyatezi olduğundan şüphelenilen ve özellikle aspirin kullanan hastalarda kanama zamanı uzayacağından; kanama, pıhtılaşma, protrombin (PT) ve aktive parsiyel tromboplastin (aPTT) zamanlarına bakılmalıdır. ${ }^{[6]}$

Uygulamada en sık, metilprednizolon (DepoMedrol R) ve triamsinolon (Kenacort-A R) kullanılır. Metilprednizolon $80 \mathrm{mg}$, triamsinolon ise 50-75 mg'lık dozlarda önerilir. Bazı araştırmacılar, düşük sodyum toksisitesi, güçlü anti-inflamatuvar etkisi, uzun süreli süspansiyon fazı nedeni ile triamsinolonu; bazıları ise, daha az irritan ve daha uzun etkili olması nedeniyle, metilprednizolonu tercih etmektedirler. Metilprednizolonun, steroidlerin santral sinir sistemindeki olası eksitabilite yanıtına bağlı olarak, konvülziyona yol açtığı savunulmuştur. Steroid ile birlikte serum fizyolojik enjekte edilir. Bu kombinasyon uygulamasının bir nedeni, depo steroid preparatında bulunan ve düşük sistemik toksik etkili polietilen glikolü seyreltmek; diğer nedeni ise, epidural aralığa yeterli volümün enjekte edilmesini sağlamaktır. Enjeksiyon için, genellikle 5-6 ml volüm önerilmektedir. ${ }^{[5-7]}$

Enjeksiyon sonrası yatak istirahati önerilen hastalar, 15 gün sonra değerlendirilir. Bazı araştırmacılar, birinci enjeksiyona yanıt alınamayan olgularda, tekrarlanan enjeksiyon önermezler. Bazıları ise, yanıt alınana kadar, 21'er gün ara ile iki ya da üç enjeksiyon yapılması gerektiğini savunurlar. Genel olarak; hastada 15 gün içinde belirgin bir düzelme oluşmuş fakat düzelme ilerlemiyorsa, enjeksiyonun tekrarı önerilir. ${ }^{[5-7]}$

Enjeksiyonun üç kereden fazla uygulanması doğru değildir. Birinci enjeksiyonda yanıt alınmayan olgularda uygulamanın tekrarı ise önerilmez.

Yönteme ait komplikasyon olarak; geçici hiperkortisizm, intra-oküler hemoraji, epidural hematom ve epidural abse gösterilmiştir. Ayrıca, ortalama \%1 olguda, dura ponksiyonu bildirilmiştir. ${ }^{[8]}$

Epidural steroid uygulaması ile, üç aydan daha kısa süredir boyun ağrısı yakınması olan olgularda \%83100 arasında başarı elde edilmiştir. Üç ila altı ay arasında bu oran \%67-81'e; bir yılın üzerinde ise \%46'ya inmektedir. ${ }^{[8]}$

\section{Epidural lizis}

Servikal bölgede, epidural aralıkta saptanan patolojinin alt seviyesinden girişim yapılır. Bu bölgelerde enjekte edilen solüsyonların spinal korda bası yapmasından çekinilir. Bu nedenle, solüsyonlar daha az volümde ve yavaş olarak enjekte edilir. ${ }^{[9]}$

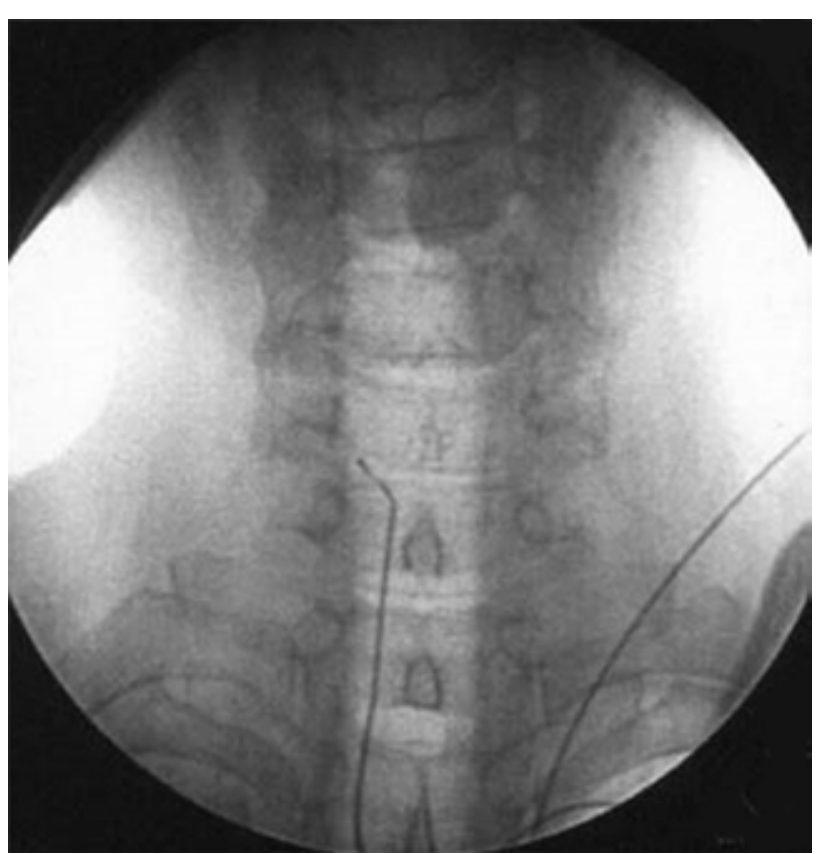

Şekil 3. Servikal Racz kateterinin AP düzlemde skopi görüntüsü.

Hasta, lateral dekubitus pozisyonda yatırılır; sağ omuz, öne kaydırılarak skopinin görüntü alanı dışına çıkarılır; lateral olarak spinöz çıkıntılar görüntülenir; 16 veya 17G R-K iğnesi kullanılır; girişim, direnç kaybı yöntemi ile gerçekleştirilir. Girişim noktasının lateralde, ağrısız tarafta kalacak şekilde işaretlenip, iğnenin paremedyan yaklaşımla ilerletilmesi önerilir. Üst servikal alanlar için en uygun girişim yeri, C7-T1 veya T1-T2 aralığıdır; iğnenin yeri, lateral ve AP görüntüleme ile saptanır. Negatif aspirasyondan sonra 1-3 ml opak maddenin dağılımı ve dolma defektleri gözlenir. Opak madde verilirken spinal kord basısı olabileceği için volüm düşük tutulmalıdır. Floroskopi cihazı AP pozisyonuna getirilerek, kateterin ucu (Racz Tun-L-Kath) adhezyon alanına ulaşıncaya kadar ilerletilir (Şekil 3). Kateterden 1-3 ml opak madde verilerek adhezyon içinde dağılımı görüntülenir. Kateterin epidural aralıkta yerleşimi tamamlanınca, cilde dikkatli bir tespitle girişim tamamlanır ve hasta yatağına alınır. ${ }^{[9]}$

Hasta yatağına alındıktan sonra, $2 \mathrm{ml}$ kısa etkili lokal anestezik (lidokain \%2) kateterden test doz olarak enjekte edilir. Lizis sırasında hipertonik salinin ağrılı enjeksiyonundan korumak için, önce \%0,25 bupivakain verilir. Lokal anestezikler, akson depolarizasyonunu önleyerek bu yapılardan elektriksel sinyallerin transmisyonunu durdurur. Afferent liflerin bloke edilmesi ile, analjezik etki oluşur. ${ }^{[9]}$ 
Lokal anestezik ile yapılan test dozunu takiben motor blok gelişmediği gözlendikten sonra, $\% 0,25$ bupivakain veya \%1 lidokain ile deposteroid (metilprednizolon veya triamsinolon) karışımı bir defa olmak üzere verilir. Karışımın volümü ve depo kortizol dozu, enjekte edilen alana göre değişir. Karışım, servikal bölge için 4 $\mathrm{ml}$ olarak hazırlanır. Triamsinolon $40 \mathrm{mg}$ olarak enjekte edilir. Test dozu ile lokal anestezik, deposteroid karışımı operasyon odasında da enjekte edilebilir. Böylece, enjeksiyonu sırasında floroskopik olarak karışımın opak maddeyle yer değiştirmesi ve adhezyon alanında dağılımı gözlenebilir. ${ }^{[9]}$

Depo-steroidlerin en belirgin etkileri, anti-inflamatuvar özellikleridir. Bu etki sayesinde, bunlar sinire bası yapan ödemli inflamasyonlu dokulardaki ödemi azaltır; vasküler akımı düzenleyici özellikleri ile de steroidler, epidural alandaki hassas yapılar üzerindeki vasküler basının azalmasını sağlar. Ayrıca, uzun süreli sinir basısı sonucu nosiseptif liflerde oluşan kontinü uyarı, steroidlerin membran stabilizasyonu etkisi ile önlenebilir. ${ }^{[9]}$

Lokal anestezik enjeksiyonundan $30 \mathrm{dk}$ sonra, \%10 hipertonik salin uygulanır. Bu işlem üç gün tekrarlanır. Enjeksiyonlardan önce, aspirasyon ile kateterin yerleşimi kontrol edilmelidir. Lokal anestezik ve hipertonik salin volümü de, uygulanan bölgeye göre değişir. Hipertonik salinin epidural enjeksiyonu, iki önemli mekanizma ile etkisini gösterir: 1) Osmotik etki ile hücrelerden sıvı migrasyonunu sağlayarak oluşturduğu güçlü anti-ödem etki sayesinde, bası yapan dokuların küçülmesini sağlar ve 2) sinir kökleri üzerinde gösterdikleri güçlü lokal anestezik etki nedeniyle, sinir irritasyonunu önler. ${ }^{[9]}$

Kontrast madde enjeksiyonunu takiben, kateterden hiyaluronidaz verilmesi de önerilmektedir. Serum fizyolojik $(10 \mathrm{ml})$ içinde 1500 ünite hiyaluronidaz enjekte edilir. Hiyaluronidazın; adhezyon çözücü, kapiller permeabiliteyi arttırıcı ve hidrolizise bağlı oluşan doku bariyerlerini önleyici etkileri nedeniyle, verilen ilaçların doku içine yayılmasını arttırıcı etkileri vardır. Böylece, enjekte edilen solüsyonların epidural aralıkta daha geniş alana dağılmaları sağlanabilir. ${ }^{[9]}$

\section{Faset eklem enjeksiyonu - faset sinir denervasyonu}

Faset eklem artrozu; osteoartroz veya dejeneratif eklem hastalığı ile birlikte görülebileceği gibi, genellikle disk dejenerasyonu veya spondilozise sekonder olarak oluşur. Faset sendrom; sıklıkla diskopati ile birlikte görülür, \%20 olguda ise tamamen bağımsızdır. Faset eklem sendromu tanısı, fizik muayene sırasında faset eklemler üzerine basmakla hassasiyet ve ağrı yakınmalarının ortaya çıkması ile konur. Hastalarda, boyun, omuz, intraskapular bölgeye yayılan ağrı ile birlikte, baş ve kulak ağrıları da olabilir.

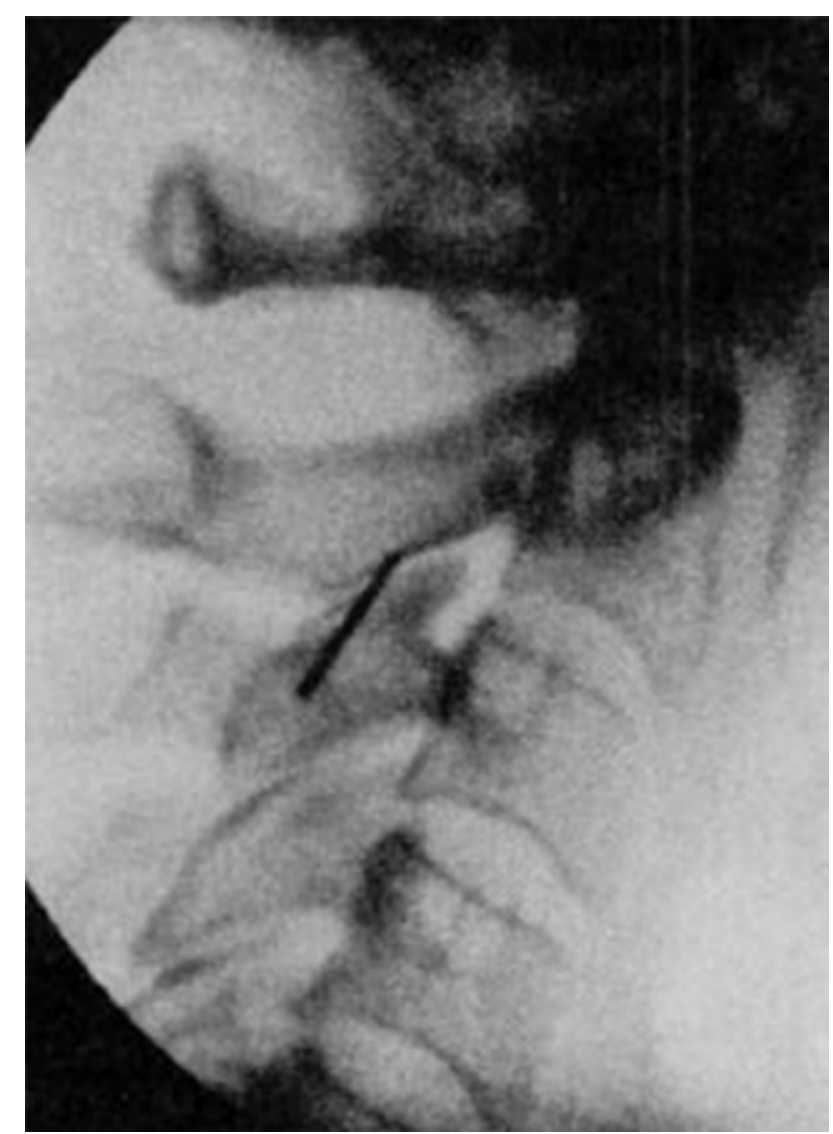

Şekil 4. Faset eklem enjeksiyonu.

Hastanın faset ekleme ait yakınmalarının tanısı, en iyi faset eklem bloğu ile konur. Faset eklem enjeksiyonu en az iki seviyeden yapılmalıdır. Bunun nedeni; segmental sinirden çıkan posterior primer ramusun arka yüze doğru ilerlemesi ve servikal faset kolonunun boşluğuna dallar vermesidir. Bu dallar, üst ve alt faset eklemlere de dallar verdiğinden, faset segmentleri denerve edebilmek için üst ve alt faset sinirleri de denerve etmek uygun olacaktır. İşlem, cerrahi koşullar altında ve skopi eşliğinde yapılmalıdır.

Diyagnostik amaçla yapılacak faset enjeksiyonlar için, hasta supin pozisyonda yatırılır. Fasetler oblik görüntü ile en iyi görülebilir. Faset eklem aralığı açık olarak görünmeye başladığında, $25 \mathrm{G}$ iğne, skopi açısına uygun olarak faset ekleme doğru ilerletilir (Şekil 4). Faset aralığına girildiğinde, $4 \mathrm{ml} \% 0,5$ bupivakain ve $40 \mathrm{mg}$ triamsinolon karışımından $0,5 \mathrm{ml}$ enjekte edilir. Bunun yanı sıra, bazı araştırmacılar faset eklem denervasyonu için kontrast madde ile kombine $\% 7$ fenol uygulamışlardır. Servikal faset eklem aralığına 0,5 ml'den daha fazla bir volüm enjekte edilemez. İğnenin damar içinde olup 

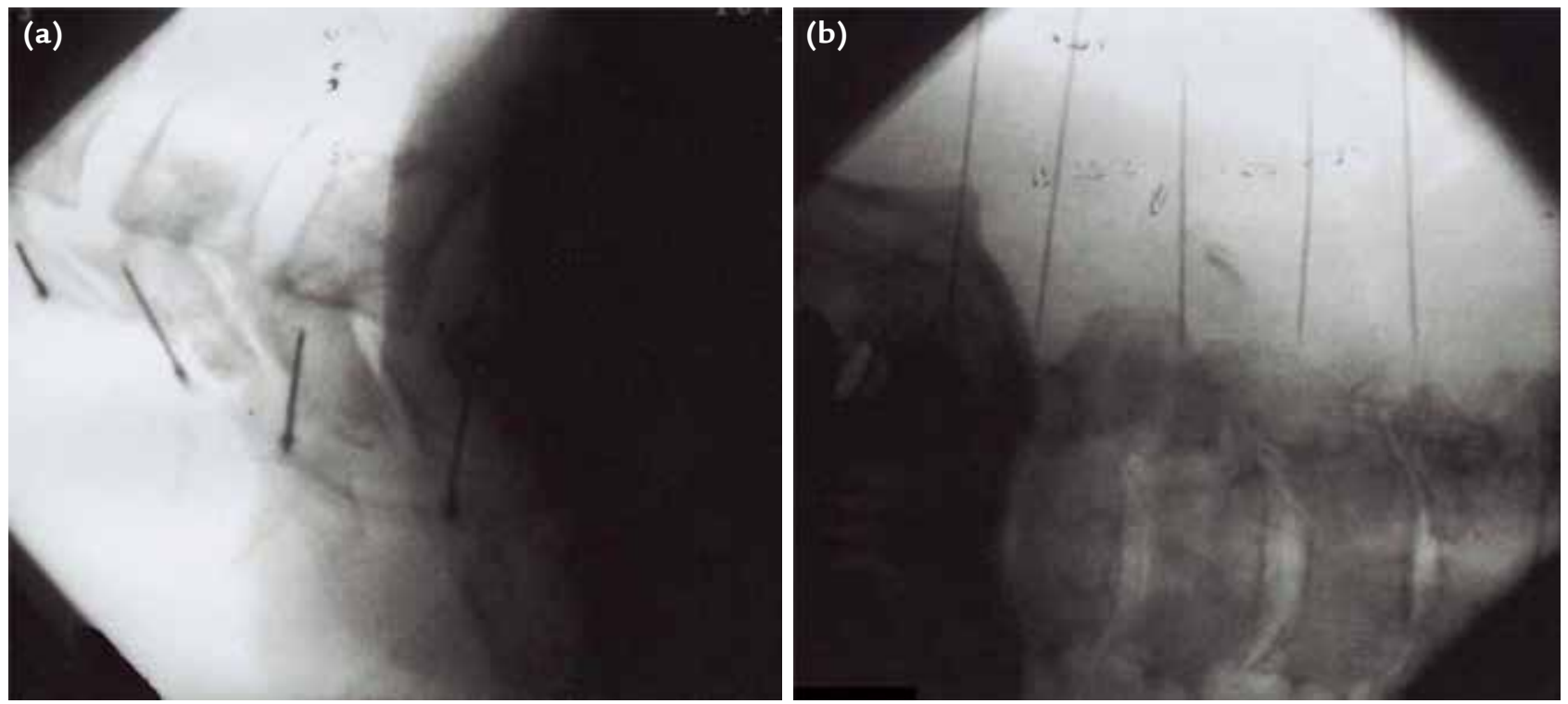

Şekil 5. a, b. Servikal faset mediyal dal bloğu, AP-lateral skopi görüntüsü.

olmadığı radyo-opak madde ile kontrol edilmelidir. Mediyal dalın bloğu için en fazla $0,5 \mathrm{ml}$, intra-artiküler enjeksiyon için ise daha düşük bir volüm kullanılmalıdır. Bazı klinisyenler tarafından diyagnostik amaçla; faset eklem içine 0,5-1 ml hipertonik salin enjeksiyonu yapılarak ağrı uyarılmaktadır. Uygulama sırasında faset ekleme girmek şart değildir. Faset eklem bloğu için, transvers çıkıntının hemen aşağısında servikal fasetin boşluğuna girilir ve posterior primer ramus bloke edilebilir. Bu işlem, uygulayıcının deneyime bağlı olmakla beraber, ortalama $\% 27$ yanlış negatif veya yanlış pozitif sonuçlar verebilir. ${ }^{[10,11]}$

\section{Faset sinir bloğu / radyofrekans termokoagülasyon ile perkütan faset rizotomi}

Lokal anestezik ajan ile yapılan test doza yanıt, hem perkütan faset denervasyonu hem de faset sinir bloğu uygulaması endikasyonu için çok önemlidir. C2C3 faset eklemi innerve eden üçüncü oksipital sinir ve C3'den C7'ye kadar mediyal dallar bloke edilir. C2C3'ün altındaki servikal faset eklemler, dorsal raminin mediyal dalları ile innerve edilir. Bu sinirler, faset eklemlerden başka derin paramedian kasları da innerve eder. C2-C3 eklemini, üçüncü oksipital sinir, greater oksipital sinirin komünikan dalı ile birlikte innerve eder. C3-C4'ten C6-C7'ye kadar faset eklemleri innerve eden servikal mediyal dal, artiküler pillar üzerinde çok küçük volümde lokal anestezik ile bloke edilebilir. Bu sinirler semispinalis kapitis kasının tendonunun altında oldukları için, lokal anestezik bu tendonun altına enjekte edilmelidir. Bu sinirin innerve ettiği cilt bölgesinde uyuşukluk olması, bloğunun yeterli olduğunun göstergesidir. ${ }^{[12]}$

Bu işlem, diğer tedavi yöntemlerinin başarılı olmadığı durumlarda uygulanır. ílk kez 1971 yılında Rees, faset eklemdeki artiküler sinirleri keserek, cerrahi girişim ile faset rizotomiyi gerçekleştirmiştir. 1973 yılında Shealy ve arkadaşları, perkütan radyofrekans termokoagülasyon yöntemi ile faset eklem denervasyonu uygulamışlardır. Günümüzde de, endikasyon konulduğunda, faset eklem denervasyonu için perkütan rizotomi tekniği uygulanmaktadır. ${ }^{[13,14]}$

Üst ve orta servikal alan (C2-C3, C3-C4, C4-C5 ve C5-C6) için, hasta skopi masasına supin pozisyonda yatırılır; pron pozisyonda da uygulama yapılabilir. Bazı klinisyenlerin daha kolay olduğunu bildirmesine karşın, pron pozisyonda girişim hasta konforu bakımından oldukça zor bir uygulamadır. Bu nedenle, bu bölümde supin pozisyonda uygulama ayrıntıları ile anlatılacaktır. Ancak, C5-C6'dan daha alt seviyedeki eklemler için, hastanın yüzüstü yatırılması gerekir. Monitorizasyonu ve intravenöz sedasyonu sağlanır. Yaklaşım lumbar bölgede olduğu gibidir. C kollu skopi cihazı hafif oblik yerleştirilir. Böylelikle, skopi segmental sinirlere paralel hale gelir. Fasetal kolonun $1 \mathrm{~cm}$ posteriorunda ve hafif kaudalde giriş noktası işaretlenir. Giriş noktasından özel kanül anterior ve kaudale, fasetal kolona değinceye kadar ilerletilir (Şekil 5). Kanül, transvers çıkıntının mediyal yüzünün üst kısmına doğru ilerletilir; kemiğe 
değdikten sonra $2 \mathrm{~mm}$ kadar geri çekilir ve kemiği sıyırıp $2 \mathrm{~mm}$ ön yüze doğru ilerletilir. Bu noktada faset sinir rahatça uyarılabilir. Kısa ve kalın boyunlu kişilerde bazen C5-C6 faset denervasyonu için posterior yaklaşım uygun olacaktır; çünkü, girişim yeri akciğer üst lobunun hemen proksimaline rastlamaktadır. Kanülün yeri, skopide anteroposterior görüntü ile doğrulanır ve termokoagülasyon işlemi gerçekleştirilir.

Lezyon için, boyu $50 \mathrm{~mm}$ ve aktif ucu $2 \mathrm{~mm}$ olan SMK kanülleri kullanılır. Kanül, faset kolonla bir sıra şeklinde duracak şekilde yerleştirilir. Oblik yaklaşım ile, kanül omurların posterioruna ve aradan faset eklem kolonunun boşluğuna doğru öne ve yukarı doğru ilerletilir. Burası, ilgili transvers çıkıntının hemen altındadır. Buradan ilgili foraminal açıklığın posterior, inferioruna ilerletilir. Segmental sinirden kaçınılmalıdır. $\mathrm{Bu}$ teknikte, hastayı oldukça rahatsız eden, segmental sinire dokunma olasılığı vardır. Bundan kaçınmak için posterior girişim tekniğini uygulayanlar da vardır. Ancak, deneyimi fazla olmayan kişilerde daha ciddi komplikasyonların oluşma olasııı̆ı yüksektir. Kanüller yerleştirildikten sonra ve lokal anestezik enjekte etmeden önce, mutlaka stimülasyon ile kontrol yapılmalıdır. Servikal bölgede, 1 ml'lik lokal anestezik solüsyon üst ve alt seviyelere yayılabilir ve yeterli stimülasyonu engelleyebilir. Stimülasyon, kanülün her pozisyonunda uygulanmalıdır. Hasta, $50 \mathrm{~Hz}$ ile yapılan stimülasyonda, posterior primer ramusa uyan boyun ve omuz bölgesinde ağıı veya sıcaklık hissetmelidir. Stimülasyon $50 \mathrm{~Hz}$ 'te 1,0 Volt'ta (veya daha az) olmalıdır; $2 \mathrm{~Hz}$, 3 Volt'ta üst ekstremitede motor fasikülasyon görülmemelidir. Bu koşullar sağlandığında, kanülden lokal anestezik olarak $0,5 \mathrm{ml} \% 2$ prilokain enjekte edilir ve RF lezyon $800^{\circ} \mathrm{C}$ isıda 90 sn süre ile gerçekleştirilir. C7, $\mathrm{C} 8$ ve $\mathrm{T} 1$ düzeyindeki posterior primer ramusu denerve edebilmek için, skopi makinesi, posterior-anterior görüntü olacak şekilde ve transvers çıkıntının ayırımı için hafif kraniyal açılanma ile yerleştirilir; $50 \mathrm{~mm}$ veya 100 'lik ve $5 \mathrm{~mm}$ aktif uçlu SMK radyofrekans kanülü, ilgili transvers çıkıntının superior ve mediyal kenarına doğru ilerletilir. Kemiğe değdikten sonra, kenarından 2 $\mathrm{mm}$ kadar anteriora ilerletilir. Daha sonra, üst servikal bölgede anlatılan işlemlerin aynısı ile lezyon gerçekleştirilir. İşlem gerçekleştirilirken, iki yönlü grafi ile kontrol yapmak güvenilirlik için gereklidir. Oblik ve lateral görüntüleme ile, foraminal açıklıktan uzakta çalışıldığı doğrulanmalıdır. T1 forameni, skapula nedeni ile tam olarak görülmeyebilir. Ancak burada, faset lezyonu öncesinde asıl takip edilmesi gereken yön, stimülasyon parametrelerinin şartlara uygun olmasıdır. Skopi görüntülerinde elektrodun yeri doğru bile olsa, stimülasyon kriterlerine uygunluk şartı aranmalıdır. Şüphe olduğunda, RF lezyondan mutlaka kaçınılmalıdır.
Servikal faset eklem denervasyonundan sonraki iyileşme dönemi çabuktur. Ağrılarda, 7-20 gün içinde azalma başlar ve hastalarda rahatlama görülür. Minör dizesteziler ve parçalı uyuşukluk meydana gelebilir, fakat bunlar tehlikeli komplikasyonlar değildir. Bazen boyun ve üst kol ağrıları ile karşılaşılabilir; kısa süreli kortikosteroid olmamasına karşın geçici nevrit ve bazen vertigo ile karşılaşılır; birkaç gün ilaç tedavisi ile bu durum da tedavi edilebilir. Bu problem, genellikle işlemi takiben 1-2 hafta içinde kendiliğinden çözümlenebilir.

\section{Sempatik gangliyon blokajı}

Boyun-omuz-kol ağrılarında, stellar gangliyon ve üst torakal sempatik zincir bloğu uygulanmaktadır. Omuz ve kola ait vazospastik hastalıkları (arteriyel disfonksiyonlar; Reynaud, skalenus antikus sendromu. vb.; venöz disfonksiyon; akut ve kronik tromboflebit, post flebit ödemi ve venöz ve arteriyel disfonksiyon; radikal mastektomiden sonra görülen cerrahi sonrası lenf ödemi ve donmalar), post-travmatik distrofi (travmatik ödem, travmatik kozalji ve fantom ağrılarında) ve herpes zosterin erken dönemi, üst ekstremitenin hiperhidrozu, sempatik blok uygulamasının endike olduğu rahatsızlıklardır.

Bu bölgeye ait rahatsızlıklarda en yaygını, blok uygulanan stellar gangliyon, inferior servikal ve birinci torasik sempatik gangliyonun tam veya parsiyel füzyonundan meydana gelmektedir. Stellar gangliyon, yedinci servikal vertebranın transvers çıkıntısının tabanı ile birinci kaburganın boynu arasında yer alır; karotis kılıfının arkasında, longus kolli kasının ventralinde bulunur; subklaviyan arter, inferior tiroid arter ve birinci interkostal arterlerle rekürren laringeal sinire komşudur; solda plevranın iki cm altındadır; C7, C8 servikal sinirler ve birinci torasik sinirlere dal verir. ${ }^{[15]}$

Blok uygularken, hasta sırtüstü yatırılır. Baş ve boyun ortaya çıkacak şekilde ekstansiyona alınır. Blok esnasında; hastaya başını oynatmaması, konuşmaması, yutkunmaması ve öksürmemesi söylenir. Hekim, hastanın blok uygulanacak tarafına geçer. Sol elin iki parmağı ile, sternokleidomastoid kas ve karotis kılıfı yana çekilir. Fossa jugularisin iki parmak laterali ve iki parmak yukarısından, iğne ile dik olarak girilir; iğne ucu hafif mediyale yönlendirilerek, vertabra gövdesine dokunana kadar ilerletilir (Şekil 6). İğne kemiğe dokununca $0,5 \mathrm{~cm}$ kadar geri çekilerek, test doz olarak $2 \mathrm{cc}$ lokal anestetik ajan verilir. Test dozu sırasında bulantı, kusma, baş dönmesi gibi bulgular ortaya çıkarsa, aspirasyonda kan gelmese bile vertebral artere girilmiş olabileceği düşünülmelidir. Bu takdirde blok durdurulmalıdır. Herhangi bir komplikasyon çıkmazsa, solüsyonun geri kalanı verilir. Hastaya diyagnostik blok olarak lidokain $(\% 0,5-1)$ veya bupivakain $(\% 0,125-0,25)$ 


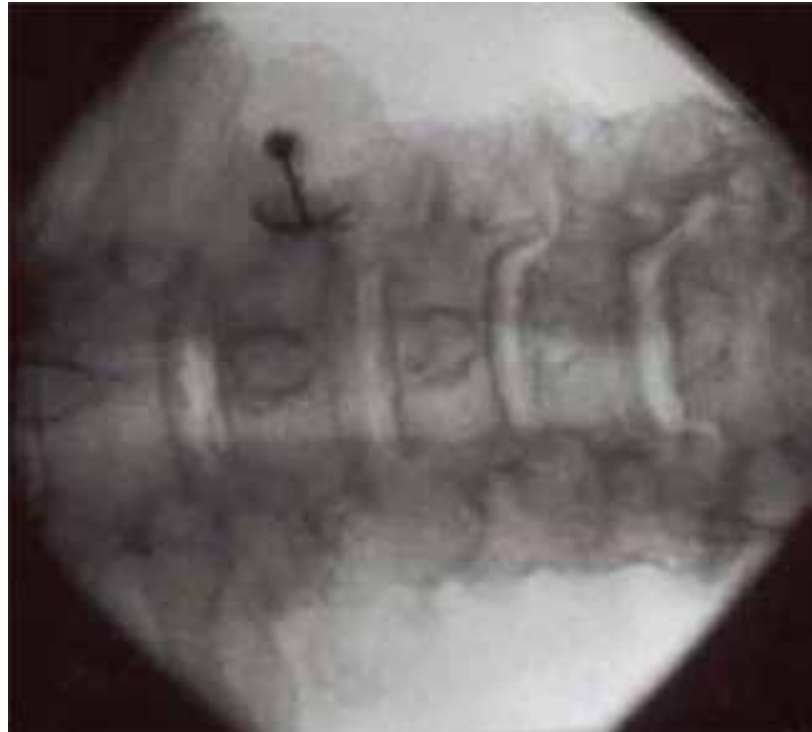

Şekil 6. Stellar gangliyon bloğu.

solüsyonundan 5-10 cc kullanılır. İki ila 15 dakika içerisinde analjezi başlar. Blok başarılı olduğu takdirde, Horner sendromunun yanı sıra aksilla, göğüs ve üst ekstremitenin tutulmasına bağlı bulgular ortaya çıkar. Tutulan tarafta, pitozis, pupilla konstriksiyonu ve enoftalmiden meydana gelen Horner sendromunun yanı sıra göz yaşarması, kol ve yüzde anhidroz, burun tıkanıklığı, kol ve yüzde sıcaklık artması gibi değişiklikler görülür. ${ }^{[15]}$

Diyagnostik bloktan uygun yanıt alındıktan sonra hastaya, kalıcı blok için radyofrekans termokoagülasyon tekniğiyle ısı lezyonu uygulaması endikasyonu verilir. Uygulama için, hasta steril koşullarda supin pozisyonda yatırılır ve $4 \mathrm{~cm}$ aktif uçlu SMK C5 kanül, skopi kontrolü altında C7 vertebra gövdesine dokunacak şekilde ilerletilir; iğnenin pozisyonu lateral ve anteroposterior görüntülerle $2 \mathrm{cc}$ opak madde de verilerek kesinleştirilir; motor stimülasyon için, $2 \mathrm{~Hz}$ frekans ile 2 Volt altında motor uyaran alınmadığı gözlenir; $75^{\circ} \mathrm{C}$ ısıda 60 sn süreyle ısı lezyonu oluşturulur. ${ }^{[16]}$

Anatomik yerleşimi bakımından riskli komşulukları bulunması nedeniyle, stellar gangliyon blokajı sırasında hayati önem taşıyan ciddi komplikasyonlar oluşabilir. Pnömotoraks, dikkatli ve titiz uygulamalarda çok seyrek görülür; subaraknoid enjeksiyon, rekürren sinir paralizisi, brakiyal pleksus paralizisi de oluşabilir. Sinir paralizisi görülse bile, geçicidir. Böyle bir durumla karşılaşıldığı takdirde, hastaya korkmaması ve durumun geçici olduğu anlatılmalıdır.
Stellar gangliyon blokajını aynı anda çift taraflı uygulamaktan kaçınmak gerekir. Kardiyak akseleratör sinirlerin blokajı ile, vagal kardiyak arrest meydana gelebilir. Horner sendromunun görülmesi, her zaman blokajın başarılı olduğu anlamına gelmez. Bu nedenle, blok dikkatlice değerlendirilmelidir. Ayrıca, lokal anestetik ajanlara bağlı toksik reaksiyon gelişebilir, astım nöbetleri uyarılabilir.

\section{Intradiskal tedavi seçenekleri}

1. Diskografi: Intervertebral diskler, kabaca iki kısımdan meydana gelmektedir. Bunlar; iç kısımda yer alan, glukozaminoglikanlardan zengin sıvı içeriğe sahip nükleus pulpozus ve bunu çevreleyen sert anulus fibrozis tabakasıdır. Başlıca yaşlanma ve tekrarlayan travmalar neticesinde, nükleus pulpozustaki sıvı içeriği düşer, disk yüksekliği azalır ve anulus fibroziste yırtıklar oluşur. Bu süreç, internal disk parçalanması şeklinde diskojenik ağrı oluşumuna ve ayrıca nükleus pulpozustaki jelatinöz içeriğin, bu yırtıklar içinden geçerek epidural alana protrüde olması yoluyla disk herniyasyonlarına yol açar. Nükleer materyalin spinal sinirlere teması da, sonuç olarak, sinir kılıfı etrafında inflamasyona ve radiküler ağrı oluşumuna neden olur.

Diskojenik boyun ağrıları, servikal intervertebral disklerdeki dejeneratif süreçler neticesinde ortaya çıkan ve genellikle boyun bölgesinde orta hatta hissedilen, omuzlarda da hissedilebilmekle birlikte kollara yayılmayan acıma şeklinde ağrılardır. Genelde, genç yaşta olan ve boyun hareketlerinin aşırı ve sık yapılmasını gerektiren işlerde çalışanlarda ortaya çıkar. Semptomlar çoğunlukla, uzun süreli oturma ve ayakta durma ile provoke olur. Fizik muayene de güç kaybı saptanmaz. Genelde fleksiyonda ağrı ve kısıtlanma göze çarpar. Manyetik rezonans (MR) görüntülerde ise disk dejenerasyon bulguları saptanır.

Diskografi, intervertebral diskin nükleus pulpozusuna kontrast madde enjeksiyonu şeklinde yapılan tanısal bir işlemdir. Günümüzde, görüntüleme yöntemlerinde saptanan anormal disk görünümüyle hastanın ağrısı arasındaki ilişkinin tespitinde kullanılmaktadır. ${ }^{[17]}$ Bir taraftan, verilen kontrast maddenin disk içerisindeki anatomik yayılımı floroskopi ile izlenirken, diğer taraftan kontrast enjeksiyonu sırasında hastada ağrının provoke olup olmadığı gözlenir. Esas kullanım alanlarından birisi de, servikal disk cerrahileri öncesinde müdahale edilecek semptomatik disklerin belirlenmesidir. ${ }^{18]}$

Servikal diskografi işlemi öncesinde, hasta fluroskopi masasına supin pozisyonunda yatırılır ve sırtomuz altı destek eklenerek boyun hafifçe hiperekstansiyona alınır. Özofagus boyun bölgesinde orta 
hattın solunda seyrettiği için, diskografi işlemleri için sağ taraftan girişim önerilir. Anteroposterior görüntülemede end plate'ler düzleştirilir. Girişim, planlanan intervertebral disk seviyesinde sternokleidomastoid kasın mediyalinden yapılır. İşaret parmağıyla, bu bölgedeki büyük damarlar laterale ve trakea mediyale hafifçe itilir. İgne, intervertebral diskin anterior lateral kenarına doğru ilerletilir. Diske girilmesinin hemen ardından, fluroskopi ile lateral görüntüye geçilerek derinlik ayarlanmalıdır. İğne ucu, disk ortasına kadar ilerletilmelidir.

Normal disk 0,25-0,5 ml sıvı içerir ve normal disklerde interdiskal enjeksiyonlar ağrıya neden olmaz. Enjeksiyon sırasında basınç kontrollü bir şekilde arttırılarak, peşi sıra 0,2 ml'lik enjeksiyonlar yapılmalı ve artan enjeksiyon ile uyumlu ağrı olması gözlenmelidir; 50 psi basınç ve üzerinde yanlış pozitif sonuçlar oluşabileceği unutulmamalıdır. Testin güvenilir olabilmesi için, en az iki dejenerasyon olmayan seviyede ağrısız disk içi enjeksiyon olduğu gözlenmelidir. ${ }^{[19]}$

İşleme ait komplikasyonlar arasında, spinal kord hasarı ve diskit sayılabilir. ${ }^{[20]}$ iş̧lem sonrası $2-7$ gün kadar hastaların ağrılarında artma olabilir ve bu sürede yutma güçlüğü yaşanabilir.

2.Intradiskal anuloplasti: Diskojenik ağrı tanısı, genel olarak füzyon cerrahisini ve çeşitli diskal artroplasti ameliyatlarını akla getirmektedir. Yapılacak cerrahinin büyüklüğü, riskleri ve olası etkinliği düşünüldüğünde, perkütan minimal invaziv yöntemler gündeme gelmiştir. Bu açıdan, farklı yöntemler söz konusu olsa da pek çoğunun ortak özelliği, anulus fibrozisin bir şekilde ısıtılması temeline dayanmalarıdır. Bu nedenle, bu yöntemler genel olarak anuloplasti adını almaktadır. Çoğu klinisyen anuloplastide işlemin nosiseptör destrüksiyonu ve doku denervasyonuna bağlı olarak etkinlik gösterdiğini düşünmekle birlikte; daha az oranda da olsa, anulusdaki kollajen yapısındaki değişikliklerin de katkısı olduğunu düşünülmektedir. ${ }^{[21]}$ Hücresel çalışmalara bakıldığında, disk dejenerasyonu sonrası TNFalfa, nitrik oksit ve matriks metalloproteinazları gibi inflamatuvar stokinlerin arttığı gözlenmiş, anuloplasti işlemi sonrasında ise kollajen yapıda degradasyon saptanamamıştır. ${ }^{[22,23]}$

Yaygın olarak kullanılan dört anuloplasti sistemi bulunmaktadır: intranükleer radyofrekans, intradiskal elektrotermal terapi (IDET), intradiskal biakuloplasti ve discTRODE. Bunlardan intranükleer radyofrekans işleminde, klasik radyofrekans elektrodu nükleus pulpozusun ortasına yerleştirilir. Ancak, nükleus içerisinde oluşturulan ISI, posterior anulusta denervasyon yapacak düzeyde anulusa yansımadığından işlem başarısız olmaktadır. İntradiskal elektrotermal terapide, yay şeklindeki tel nükleus ile anulus arasında posterior anulus boyunca yerleştirilir. Ancak burada da, oluşan ısı anulusun sadece kısıtlı bir kısmını etkilemektedir. DiskTRODE sisteminde, radyofrekans elektrodu posterior anulus boyunca yerleştirilmekte ve posterior anulus ısıtılmaktadır. Son olarak, intradiskal biakuloplastide, iki radyofrekans elektrodu bilateral olacak şekilde posterior anulusa yerleştirilmekte ve böylece bipolar radyofrekans uygulanarak optimal ısıtma sağlanmaya çalışılmaktadır. Son yıllardaki yaygın kanı, intranükleer radyofrekans ve discTRODE yöntemlerinin başarısız olduğu, IDET ve daha fazla oranda intradiskal biakuloplastinin ise seçilmiş olgularda yarar sağlayabileceği yönündedir. ${ }^{[24]}$

İntradiskal anuloplasti işlemlerinin genel olarak sık görülen yan etkileri, geçici ağrı şiddetlenmesi ve vazovagal reaksiyonlardır. Nadir olmakla birlikte ciddi komplikasyonları arasında ise; diskit, spinal abse ve vertebral osteomiyelit gibi enfeksiyöz komplikasyonlar sayılabilir. ${ }^{[25]}$

3.Intradiskal ozon enjeksiyonu: Ozon, üç oksijen atomundan oluşan, keskin kokulu, havadan ağır ve renksiz bir gazdır. TNF-alfa, IL-1 ve IL-6 başta olmak üzere, inflamatuvar sitokinleri ciddi olarak azaltır. Bakterisidal ve fungisidal bir etkinliği mevcuttur; çok kuvvetli oksidan bir ajandır. Hastalara oksijen azot karışımı şeklinde uygulanır. Oldukça kararsız bir molekül olup, kısa zamanda oksijene dönüşür; bu nedenle, kullanılacağı ortamda hazırlanmalıdır.

Servikal ve lomber disk hernisi olan hastalarda intradiskal ozon kullanımı, 1980'li yıllarda uygulanmaya başlanmıştır. İntervertebral diskin nükleus pulpozusuna enjekte edilen ozon, kuvvetli oksidan etkisi sayesinde, proteoglikan yapıları parçalar ve sülfat yan zinciri olan negatif yüklü yapıları nötralize eder. Bunun sonucunda, intervertebral diskin su tutma kapasitesi azalır, disk büzülür ve protrude olan disk hacmi küçülür. Sonuç olarak, hem semptomatolojinin rahatlamasında hem de MR görüntülemelerde, herniye olan disk boyutunun azalmasında etkili görünmektedir. ${ }^{[26,27]}$

\section{Spinal kord stimülasyonu (SKS)}

Stimülasyon yöntemlerinin ağrı tedavisinde kullanımı ile ilgili ilk sistemli araştırmalar 1960'larda başlamıştır. Aynı yıllarda, Wall ve Melzack'ın kapı kontrol teorisi ile etki mekanizması açıklanmaya çalışılan bu yöntemlerin mekanizması, günümüzde de tam olarak aydınlanmamıştır. Stimülasyon uygulaması ile analjezik etkinin, spinal kord seviyesinde, endojen opioid sistemin ve sinaptik kapı sisteminin aktivasyonu ile oluştuğu düşünülmektedir. 

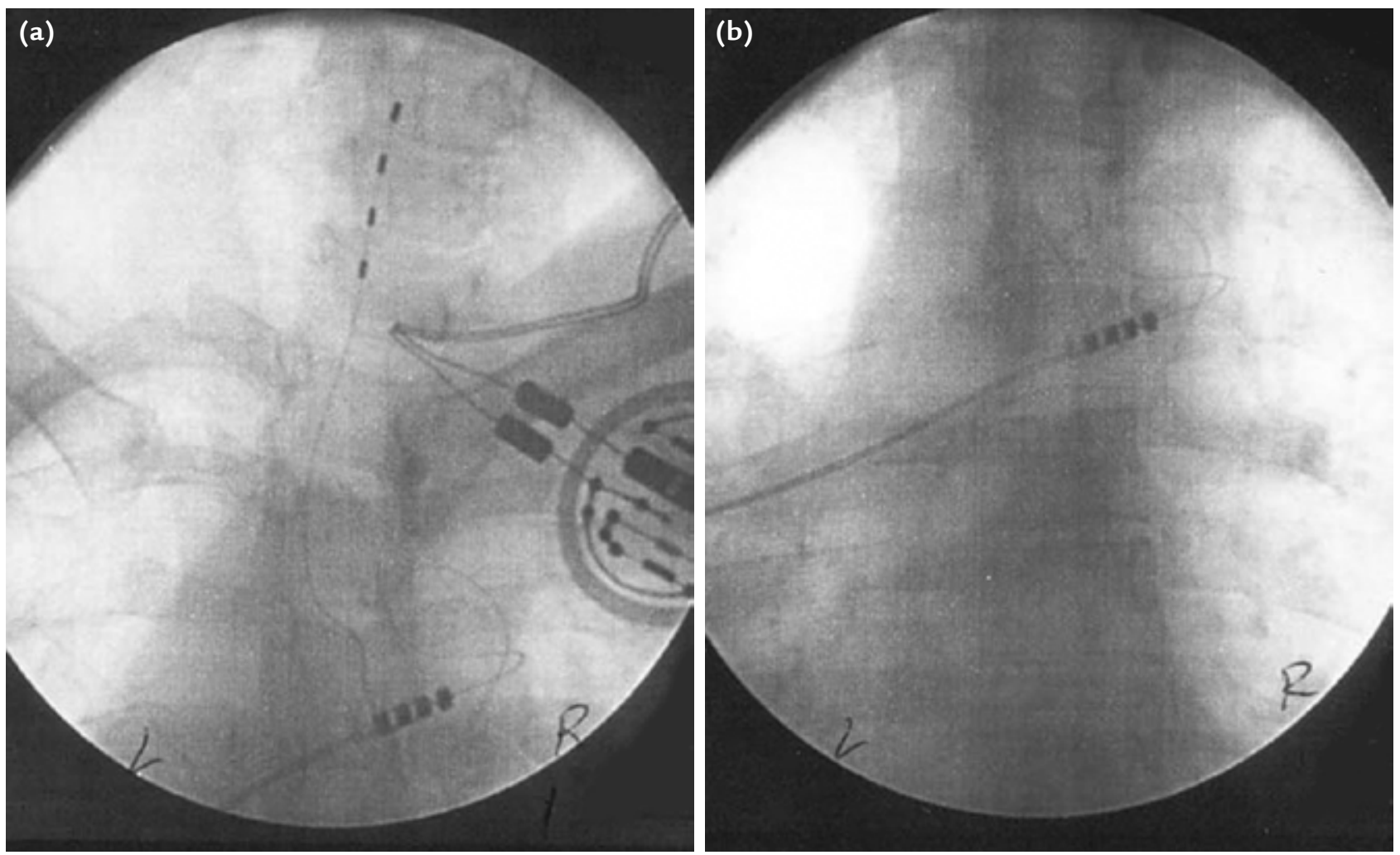

Şekil 7. a, b. Servikal spinal kord stimülasyonu.

SKS uygulamasında hasta seçim kriterleri, yöntemin başarısı için çok önemlidir. Hastanın ağrısının organik bir nedeni bulunmalıdır. Ağrı şikayetleri çok sık ve şiddetli olmalı, diğer tedavi yöntemlerinden yeterli yanıt alınmamış olmalıdır. SKS uygulanması düşünülen hastalar psikiyatrik açıdan kontrol edilmeli ve majör psikiyatrik sorunlarının veya ilaç bağımlılıklarının olmadığı ortaya konmalıdır. TENS (Transcutaneous Electrical Nerve Stimulation) uygulanan ve olumlu yanıt alınan hastalarda, SKS uygulamasından da iyi sonuç alınabilir.

Hasta seçimi, endikasyonun doğru konulması ve tekniğin gelişmesi ile, SKS uygulamasına ait başarılı sonuçlar elde edilmektedir. Spinal kord lezyonu, fantom ağrısı, periferik nöropati ve periferik vasküler hastalık, radikülopati, SKS için özgün endikasyonlardır. Şiddetli kanser ağrılarında, vertebral metastaz bulunması durumunda SKS uygulanmaması önerilir.

ilk kez 1967 yılında Shealy tarafından uygulanmıştır. Başlangıçta laminektomi ile yerleştirilen elektrodlar, günümüzde perkütan yerleştirilecek şekilde geliştirilmiştir. Skopi altında yüzüstü pozisyonda veya yan yatar pozisyonda yatırılan hasta, steril koşullarda girişim için hazırlanır; 16 G R-K iğne ile girişim yapılır. RK iğnesinin ucu özel eğimlidir ve elektrodun ileri geri oynatılmasını sağlar. İ̆nenin girişi, paramedyan ve $45^{\circ}$ yakın açı ile gerçekleştirilir; bu sayede kateterin hareketi daha kolay olacaktır. Daha sonra, skopi ile izlenerek ilerletilen kateter, üst torakal bölgeden servikal bölgede uygun alana yerleştirilir (Şekil 7). Bu sırada değişik stimülasyon modları ile uyaran verilerek, hastanın ağrılı alanının en iyi kapsandığı yerde elektrod tespit edilir. Bu şekilde yerleştirilen geçici elektrod ile alınan yanıt yeterli olursa, aynı teknikle kalıcı sistem yerleştirilir. ${ }^{[28]}$

En sık rastlanan komplikasyon, elektrod dislokasyonu ve migrasyonudur. Bu komplikasyonlar ile sistem sonlandırılamaz ve çeşitli revizyonlar ile tekrar sürdürülebilir.

Hasta seçiminin doğru yapılması ve tekniğin iyi kullanılması ile, gün geçtikçe daha iyi sonuçlar alınmaktadır. Birçok araştırmacıya göre, başarılı sonuç oranı \%48-75 arasında değişmektedir. Yöntemin uzun süreli takibine ait ortalama olarak \%50 başarılı sonuçlar alınmıştır. 


\section{SONUÇ}

Günümüzdeki ekonomik ve teknolojik gelişmeler göz önüne alındığında, yaşam şartlarındaki farklılaşmalarla, boyun ağrıları gibi bazı ağı modellerinin sıklığında artış görülmektedir. Ancak, bu duruma paralel olarak, tanı ve tedavi alanında elde edilen gelişmeler ışı̆̆ında, yeni tedavi modalitelerinin geliştirilmesi ve klinik pratikte uygulanması mümkün olmuştur. İnsanların yaşam sürelerindeki artışa bağlı olarak, yaşlanmaya bağlı görülme sıklığı artan boyundaki dejeneratif hastalıklar, önemli sağlık sorunları arasındaki yerini almaktadır. Dikkatlice alınan anamnez, temel fizik muayene yöntemleri, yerinde ve doğru olarak kullanılan radyodiyagnostik ve elektrofizyolojik yöntemlerin yardımıyla; erken ve doğru tanıya ulaşılabilmekte ve etkili tedavi yöntemleri, hastaların kısa sürede normal yaşamlarına dönmelerine yardımcı olabilmektedir. Tüm enjeksiyon tekniklerinin uygulanması sırasında, mutlaka sterilizasyon kurallarına dikkat edilmesi ve mümkün olduğu sürece bu tekniklerin floroskopi yardımıyla uygulanması gerekir. Enjeksiyon tekniklerinin uygulanması sırasında ve sonrasında ortaya çıkabilecek komplikasyonlar düşünüldüğünde, hiçbir işlemin küçümsenmemesi ve kurallara uygun olarak yapılması gerektiği unutulmamalıdır.

\section{KAYNAKLAR}

1. Bovim G, Schrader H, Sand T. Neck pain in general population. Spine (Phila Pa 1976) 1994;19(12):1307-9.

2. Cailliet R. Neck and Arm Pain, 3rd ed. Philadelphia: F. A. Davis Company; 1991.

3. Leonardi $\mathrm{M}$, Pfirrmann CW, Boos $\mathrm{N}$. Injection studies in spinal disorders. Clin Orthop Relat Res 2006;443:168-82.

4. Datta S, Everett CR, Trescot AM, Schultz DM, Adlaka R, Abdi S, Atluri SL, Smith HS, Shah RV. An updated systematic review of the diagnostic utility of selective nerve root blocks. Pain Physician 2007;10(1):113-28.

5. Slipman CW, Lipetz JS, DePalma MJ, Jackson HB. Therapeutic selective nerve root block in the nonsurgical treatment of traumatically induced cervical spondylotic radicular pain. Am J Phys Med Rehabil 2004;83(6):446-54.

6. Kwon JW, Lee JW, Kim SH, Choi JY, Yeom JS, Kim HJ, Kwack KS, Moon SG, Jun WS, Kang HS. Cervical interlaminar epidural steroid injection for neck pain and cervical radiculopathy: effect and prognostic factors. Skeletal Radiol 2007;36(5):431-6.

7. Vallée JN, Feydy A, Carlier RY, Mutschler C, Mompoint D, Vallée CA. Chronic cervical radiculopathy: lateralapproach periradicular corticosteroid injection. Radiology 2001;218(3):886-92.

8. Derby R, Lee SH, Kim BJ, Chen Y, Seo KS. Complications following cervical epidural steroid injections by expert interventionalists in 2003. Pain Physician 2004;7(4):445-9.

9. Racz GB, Holubec JT. Lysis of adhesions in the epidural space. In: Racz GB, editor. Techniques of neurolysis. Boston: Kluwer Academic Publishers; 1989. p.57-72.
10. Aprill C, Dwyer S, Bogduk N. Cervical zygapophysial joint pain patterns II. A clinical evaluation. Spine (Phila Pa 1976) 1990;15(6):458-61.

11. Barnsley L, Lord S, Wallis B, Bogduk N. False-positive rates of cervical zygoapophyseal joint blocks. Clin J Pain 1993;9(2):124-30.

12. Sluijter ME. Radiofrequency lesions in the treatment of cervical pain syndromes. Radionics procedure technique series. Burlington, MA: Radionics; 1990. p.1-19.

13. Boswell MV, Shah RV, Everett CR, Sehgal N, Brown AM, Abdi S, Bowman RC 2nd, Deer TR, Datta S, Colson JD, Spillane WF, Smith HS, Lucas LF, Burton AW, Chopra P, Staats PS, Wasserman RA, Manchikanti L. Interventional techniques in the management of chronic spinal pain: evidence-based practice guidelines. Pain Physician 2005;8(1):1-47.

14. Geurts JW, van Wijk RM, Stolker RJ, Groen GJ. Efficacy of radiofrequency procedures for the treatment of spinal pain: a systematic review of randomized clinical trials. Reg Anesth Pain Med 2001;26(5):394-400.

15. Chaturvedi A, Dash $\mathrm{HH}$. Sympathetic blockade for the relief of chronic pain. J Indian Med Assoc 2001;99(12):698-703.

16. Forouzanfar $T$, van Kleef $M$, Weber WE. Radiofrequency lesions of the stellate ganglion in chronic pain syndromes: retrospective analysis of clinical efficacy in 86 patients. Clin J Pain 2000;16(2):164-8.

17. Manchikanti L, Dunbar EE, Wargo BW, Shah RV, Derby R, Cohen SP. Systematic review of cervical discography as a diagnostic test for chronic spinal pain. Pain Physician 2009;12(2):305-21.

18. Singh $\mathrm{V}$. The role of cervical discography in interventional pain management. Pain Physician 2004;7(2):249-55.

19. Schellhas KP, Smith MD, Gundry CR, Pollei SR. Cervical discogenic pain. Prospective correlation of magnetic resonance imaging and discography in asymptomatic subjects and pain sufferers. Spine (Phila Pa 1976) 1996;21(3):300-11.

20. Guyer RD, Collier R, Stith WJ, Ohnmeiss DD, Hochschuler SH, Rashbaum RF, Regan J. Discitis after discography. Spine (Phila Pa 1976) 1988;13(12):1352-4.

21. Kapural L. Indications for minimally invasive disk and vertebral procedures. Pain Med 2008;9(S1):S65-72. Crossref

22. Podichetty VK. The aging spine: the role of inflammatory mediators in intervertebral disc degeneration. Cell Mol Biol (Noisy-le-Grand) 2007;53(5):4-18.

23. Kapural L, Mekhail N, Hicks D, Kapural M, Sloan S, Moghal N, Ross J, Petrinec D. Histological and temperature distribution studies of a novel bipolar radiofrequency heating system in degenerated and nondegenerated human cadaver lumbar discs. Pain Med 2008;9(1):68-75. Crossref

24. Kapural L, Hayek S, Malak O, Arrigain S, Mekhail N. Intradiscal thermal annuloplasty versus intradiscal radiofrequency ablation for the treatment of discogenic pain: a prospective matched control trial. Pain Med 2005;6(6):425-31. Crossref

25. Kapural L, Cata J. Complications of minimally invasive procedures for discogenic pain. Tech Reg Anesth Pain Med 2007;11(3):157-63.

26. Alexandre A, Corò L, Azuelos A, Buric J, Salgado H, Murga M, Marin F, Giocoli H. Intradiscal injection of oxygen-ozone gas mixture for the treatment of cervical disc herniations. Acta Neurochir 2005; 92:79-82.

27. Buric J, Rigobello L, Hooper D. Five and ten year follow-up on intradiscal ozone injection for disc herniation. Int J Spine Surg 2014;8. doi: 10.14444/1017

28. Vallejo R, Kramer J, Benyamin R. Neuromodulation of the cervical spinal cord in the treatment of chronic intractable neck and upper extremity pain: a case series and review of the literature. Pain Physician 2007;10(2):305-11. 